\title{
Toward a Comprehensive Understanding of Corporate Reputation: Concept, Measurement and Implications
}

\author{
Hamed M. Shamma ${ }^{1}$ \\ ${ }^{1}$ School of Business, American University in Cairo, New Cairo, Egypt \\ Correspondence: Hamed M. Shamma, Department of Management, School of Business, American University in \\ Cairo, P.O. Box 74, New Cairo 11835, Egypt. Tel: 20-2-2615-3278. E-mail: shamma@aucegypt.edu
}

Received: April 16, 2012 Accepted: July 23, 2012 Online Published: August 16, 2012

doi:10.5539/ijbm.v7n16p151 URL: http://dx.doi.org/10.5539/ijbm.v7n16p151

\begin{abstract}
Corporate reputation is more important than ever. The highly turbulent business environment, increased public expectations, and pressure from different stakeholder groups have all contributed to the increased importance of examining and managing a company's reputation. Academic scholars have been studying corporate reputation for the past two decades, with special attention during the past decade. This is evidenced by the special journals on corporate reputation such as the Corporate Reputation Review, special issues in various journals on corporate reputation and many academic conferences on this important research topic. Today, with the abundance of research on corporate reputation it was important to look back and reflect on these studies. It is important to provide an overall framework for understanding corporate reputation and its underlying components and measures. Accordingly, this paper aims to review the literature on corporate reputation, by examining the concept, its measurement, perspectives and overall implications on organizations. This paper offers a synthesis of the concept of corporate reputation as well as some implications for managers who want to actively manage their reputations.
\end{abstract}

Keywords: corporate reputation, definition, measurement, implications

\section{Introduction}

In today's highly competitive, dynamic and turbulent business environment, companies strive to search for ways to differentiate their offerings and build favorable relationships with a company's stakeholder groups. Reputation is an important means by which companies can maintain a sustainable competitive advantage and endure a long term relationship with multiple stakeholder groups (Boyd et al, 2010). It is the most valuable intangible asset that helps sustain the organization throughout its lifetime. Further, a favorable corporate reputation is thought to safeguard an organization at times of crises. However, it can only take one negative incident to damage a reputation, quoting Warren Buffet:

"It takes 20 years to build a reputation and five minutes to ruin it. If you think about that, you'll do things differently." - Warren Buffet

Examining corporate reputation is becoming more important today than ever. This is due to many factors such as: increased public awareness about corporate actions and issues, increased requirement for transparency, higher expectations by multiple stakeholder groups, word-of-mouth and online communication, customer's personal experience with a company's products and services, effect of the influence of opinion leaders, growth in interest groups and increased attention from media have all contributed to the importance of assessing and actively managing a company's reputation.

In the past, companies applied a passive approach to manage corporate reputation. When companies were faced with a crisis, they would form a task force that would work on solving the crisis as quickly as possible in order to minimize its negative effects on the organization and go back to normal business. However, there was nothing done to actively manage reputation on the long term. This reactive strategy was found to be unsustainable in today's environment. Companies are now more vulnerable to their existence and sustenance so long as they do not actively and proactively seek to manage their reputations. Companies such as Enron, failed to survive because of lack of reputation management. Companies have to actively manage their reputations and not merely react when they are faced with a crisis. 
Corporate reputation has been the focus of much of the academic research during the past two decades (Logsdon and Wood 2002). In recent years, there has been increased emphasis on the value of the reputation by both scholars and practitioners (Fombrun and Van Riel 2004; Bromley 2002; Chun, 2005; Hillenbrand and Money, 2006; Helm, 2007; Chettamronchai, 2010). With the significant increase in the number of research papers on corporate reputation, there has been a clear fragmentation and diversion to the meaning of corporate reputation, the essence of the concept, its measurement and its managerial implications. Thus, there is a need to synthesize these studies and offer a more integrated perspective to the concept of corporate reputation. Accordingly, this paper aims to offer a synthesized perspective of corporate reputation as a concept, measurement tool and managerial perspective.

This study focuses on several aspects about corporate reputation. First, it examines the corporate marketing landscape which is the area in marketing that covers concepts at the corporate level. Second, the different measures and perspectives for corporate reputation are discussed. Third, the antecedents and consequences of corporate reputation are presented. Finally, the importance of actively managing corporate reputation is highlighted as well as an agenda for future research. In the following section, an overview about the corporate marketing landscape and its underlying components are highlighted.

\section{Corporate Marketing Landscape}

Corporate marketing is the area in marketing that encompasses concepts that address issues at the corporate level as opposed to the product level (Balmer and Greyser 2006). The corporate marketing landscape includes concepts such as: corporate reputation, corporate image, corporate identity, corporate branding, corporate communications, corporate personality and corporate associations. These concepts have different meanings, and thus highlighting their differences is necessary to understand their true meaning. Figure 1 below shows the different elements of the corporate marketing landscape.

In the following section the concepts that comprise the corporate marketing landscape are explained in details.

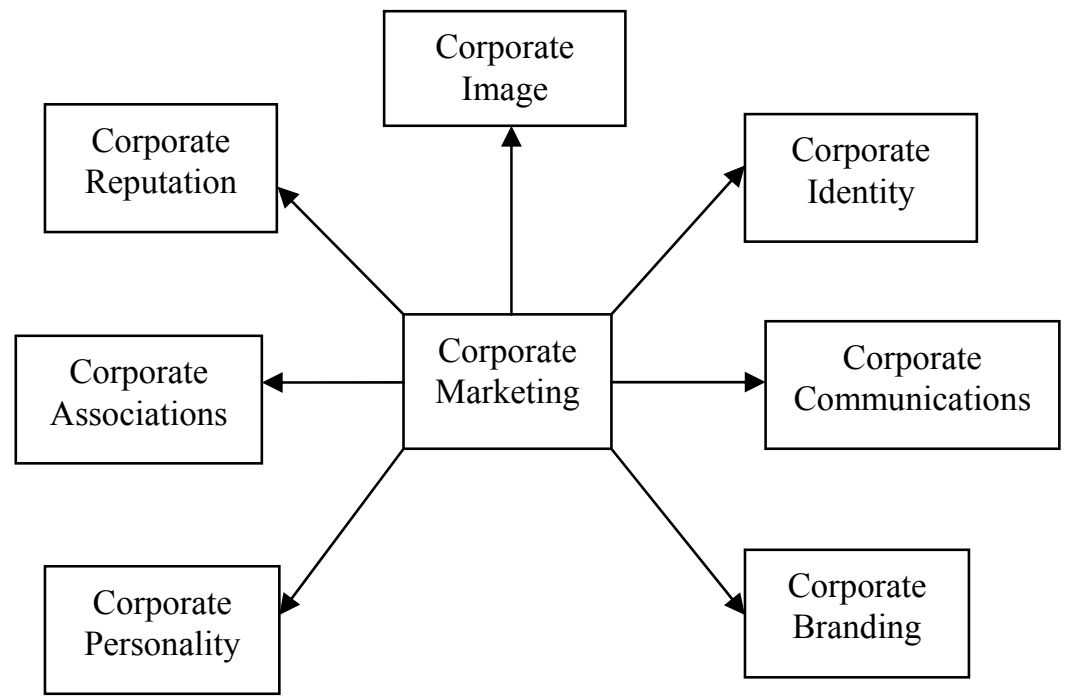

Figure 1. Corporate marketing landscape

\subsection{Corporate Image}

The term corporate image is often used to refer to an organization's views about external stakeholders' perceptions with respect to an organization (Davies et al. 2001). Brown et al. (2006) refer to this as the construed image. Construed image encompasses all the associations that internal organizational members have about external stakeholders' perceptions of the organization. It asks the question "What does the organization believe others think of the organization?" (Brown et al. 2006). Intended image refers to the associations held by organizational leaders that are to be projected to important stakeholders. It asks the question "What does the organization want others to think about the organization?" (Brown et al. 2006).

Corporate image focuses on the "outside world's overall impression of the company including the views of customers, shareholders, the media, the general public" (Hatch \& Schultz, 2003). Fombrun and Shanley (1990) suggest that various informational signals from organizations such as: information about firms' structural positions 
within organizational fields, market and accounting signals indicating performance, institutional signals indicating agreement to social norms, strategy signals indicating strategic postures all contribute to company image. Following are some definitions for corporate image from the literature:

"View of the organization developed by its stakeholders; the outside world's overall impression of the company" (Hatch and Schultz 2003).

"Mental associations that organization members believe others outside the organization hold about the organization" (Brown, Dacin, Pratt and Whetton 2006).

"A short-term, or momentary, perspective of an organization at a particular point in time" (Bick, Jacobson, and Abratt 2003).

Bullmore (1984) highlights that image research focuses primarily on structural entities in the marketplace such as: stores, brands and corporations. Advertisements are the main vehicle for transferring images from these entities to consumer's mind (Bullmore, 1984).

\subsection{Corporate Identity}

Corporate identity is the internal stakeholders' perceptions about an organization (Albert and Whetten 1985). Organizational identity refers to the associations held by the organizational members about an organization. Identity asks the question "Who are we as an organization?" (Brown et al. 2006). Bromley (2001) suggests that corporate identity is that set of attributes that distinguishes one organization from another. Following are some of the various definitions of corporate identity that are prominent in the literature.

"The construed external image of the firm. What a member believes outsiders think about the organization" (Dutton, Dukerich, and Harquail, 1994).

"What members perceive, feel and think about their organization: a collective, commonly-shared understanding of the organizations distinctive values and characteristics" (Hatch and Schultz, 1997).

"The set of values and principles employees and managers associate with a company" (Fombrun, 1996).

"What employees feel and think about their organization. It focuses on questions relating to organizational culture. It gives a business its distinctiveness" (Balmer, 2001).

"A strategic manifestation of corporate-level vision and mission, underpinned by the strategies which a corporation employs in its operation or production" (Melewar and Wooldridge, 2001).

\subsection{Corporate Associations}

Brown and Dacin (1997) postulated "corporate associations" as a term that refers to all the underlying information and perceptions one has toward a company. Corporate associations describe the "cognitions, affects (i.e. moods and emotions), evaluations (attaching to specific cognitions or affects), summary evaluation and/or patterns of associations (e.g. schema, scripts) with respect to a particular company" (Brown 1998).

Brown and Dacin (1997) divided the corporate associations into two main dimensions: (1) corporate ability associations, which included items such as: leadership in industry, research and development capability and progressiveness of company; and (2) corporate social responsibility associations, which included items such as: concern for the environment, involvement in local communities, and corporate giving to worthy causes. Later, Berens and Van Riel (2004) proposed a measure for corporate associations which included: social expectations, corporate personality traits and trust toward the company.

Brown and Dacin (1997) postulated that corporate associations are composed of: (1) corporate ability associations which were determined by: (a) leadership in industry, (b) research and development capability, (c) progressiveness of company, and (2) corporate social responsibility associations, which were perceived to be: (a) concern for the environment, (b) involvement in local communities, and (c) corporate giving to worthy causes.

Berens and Van Riel (2004) have identified three main conceptual streams relating to corporate associations. Their first stream related to the social expectations people have regarding the organization; the second stream was based on the corporate personality traits that people have toward a company; and the third stream was the degree of trust toward the company.

\subsection{Corporate Communication}

Corporate communication is defined as "an instrument by means of which all consciously used forms of internal and external communications are harmonized as effectively and efficiently as possible to create a favorable basis for relationships with the groups upon which the company is dependent" (Van Riel, 1995). It is an important 
method by which corporate marketers communicate messages about an organization to multiple stakeholder groups.

Corporate communications is viewed as a core element to reach multiple stakeholders and align stakeholder's interests with company interests. Corporate communications can be used to better understand the needs of multiple stakeholders and integrate them into a company's internal culture. The value of corporate communication is that it can be used to reach all of a company's stakeholder groups collectively as opposed to communicating with specific stakeholder groups separately.

In addition to its primary role as a means for communicating with multiple stakeholders, corporate communications can help enhance and support a company's reputation. According to the signaling theory, corporate communications can be used to provide signal information to stakeholders when they are confronted with uncertainty or incomplete information about a firm (Fombrun and Shanley, 1990). Corporate communications helps reduce uncertainty stakeholders have about a company's actions. Further, Fombrun and Rindova (1998) note that "communications that make a firm transparent enable shareholders to appreciate the firm's operations better, and also facilitate ascribing better reputation." Burke (1998) also emphasizes the importance of corporate communication by highlighting its significance in helping to "sustain, foster and develop an organization's reputation."

Several qualitative studies have supported the effect of corporate communication management on reputation building (e.g. Foreman and Argenti, 2005). A good quality communication program might provide a positive evaluation about a company. This is because a good quality communication program provides indication that a company is effective not only in the message it is conveying, but may extend to other features about a corporation as well. An effective corporate communications program can enhance perceptions about the activities that are relevant to specific stakeholders and can also trigger an overall positive evaluation about the company as a whole.

Signaling theory (Turban and Greening, 1997; Spence, 1974) is an important component of corporate communications. This is because perceptions about a strength or weakness in one area of a firm may affect perceptions about other areas in a firm. Signaling theory suggests that a strong or weak performance in an area of reputation could spill over into other areas. This may result in more favorable or unfavorable perceptions across the multiple dimensions of corporate reputation. When individuals are faced with incomplete information, they use the information that they have as signals about the unknown aspect of a firm (Spence, 1974).

Signaling theory has been used in marketing to support the view that consumers exposed to new products with a familiar brand name extend the characteristics of the brand to the newly introduced product (Wernerfelt, 1998). In human resources, potential employees use a firm's visible characteristics as a signal of the work environment (Turban and Greening, 1997). In corporate reputation, stakeholders use a firm's corporate communication message as signals about a company's reputation.

\subsection{Corporate Branding}

Corporate branding is seen to have emerged as a key concept in the late 1990s (Burt and Sparks, 2002). The corporate brand was defined as "the visual, verbal and behavioral expression of an organization's unique business model" (Knox and Bickerton, 2003). Corporate branding, internally, is seen to signal messages about a desired culture and externally to facilitate customers' desires to look deeper into the corporation and, through building respect and trust with the corporation's offerings, to encourage consumers to accept the corporation's promises about other offerings (Balmer, 2001, de Chernatony, 1999). It is also thought of as: "the communication interface between the organization and its stakeholders (Hatch and Schultz, 2003). The visual, verbal and behavioral expression of an organization's unique business model (Knox and Bickerton, 2003).

Some researchers define corporate branding as corporate identity or corporate image (de Chernatony, 2001, Ellwood, 2000, Ind, 1997, Mottram, 1998). Balmer (2001a) expressed corporate branding in terms of organizational identity. He has defined corporate branding as the "conscious decision by senior management to distil and make known the attributes of the organization's identity in the form of a clearly defined branding proposition" (Balmer, 2001a, p. 281). Yet some important differences have been identified between the concepts of corporate identity and the corporate brand (Balmer and Greyser, 2003). These scholars see that, while the identity concept is applicable to all entities (i.e., a "necessary" concept), a corporate brand is contingent (i.e., determined by conditions or circumstances).

\subsection{Corporate Personality}

Corporate personality is widely used by many scholars and practitioners to personify the character of an 
organization (e.g. Olins, 1978; Davies, da Silva and Roper, 2003). It is a useful strategy for corporate branding and differentiation. Further, a measurement scale has been developed to measure the corporate personality for an organization.

Davies et al., (2001), developed the corporate personality scale, which is a scale that would measure both internal (employee) and external (customer) perspectives about corporations. The corporate personality scale is a scale that could be used to characterize the personality of an organization. It is used as a way to "personify" the characteristic of an organization. The results of Davies et. al's (2001) study highlighted that there are seven dimensions for corporate personality, they are:
1) Agreeableness
2) Enterprise
3) Competence
4) Chic
5) Ruthlessness
6) Machismo
7) Informality

\subsection{Corporate Reputation}

Corporate reputation has been defined by many scholars in various ways (Caruana, 1997). The meaning of reputation remains a matter of debate by many scholars (Devine and Halpern, 2001). Compared to other concepts in the corporate marketing landscape, corporate reputation is often seen as a "general view of the company" (Bick, Jacobson \& Abratt, 2003, p 853). It is seen as a comprehensive concept that comprises all aspects of corporate marketing including: corporate image, corporate identity, corporate branding, corporate personality, corporate associations and corporate communications. It is the integration of all these concepts together that makes up corporate reputation. Corporate reputation is sometimes viewed as the external stakeholders' perceptions about an organization (Davies and Miles 1998; Hatch and Schultz 1997). It refers to the associations that external constituencies have about an organization. It asks the question "What do stakeholders actually think of the organization?" (Brown et al. 2006).

This has resulted in fragmented definitions of corporate reputation, misunderstanding about what constitutes corporate reputation and misuse of corporate reputation with other elements of corporate marketing. Thus, it is important to define what is meant by corporate reputation and have a better understanding of what it comprises. Following are some of the most common definitions for corporate reputation cited in the literature:

"A perceptual representation of a company's past actions and future prospects that describes the firm's overall appeal to key constituents compared to other leading rivals." Fombrun (1996).

"It is a reflection of stakeholder's views about an organization over time" (Saxton, 1998).

“A stakeholder's overall evaluation of a company over time."(Gotsi and Wilson, 2001).

"Lasting perception held of an organization by an individual, group or network that forms a collective system of beliefs and opinions that influences people's actions with regards to an organization" (Balmer 2001).

The common dimension among the above definitions is that they emphasize that reputation is related to a specific period of time.

It was observed that there is no single definition that was commonly accepted regarding corporate reputation which resulted in: numerous definitions for corporate reputation and (b) broad differences in meaning among the definitions. Thus, it was important to categorize these definitions and analyze the overall themes of these definitions. Next, are the different clusters of meanings that have been assigned to corporate reputation to get an overview of the different groups.

\section{Clusters of Corporate Reputation}

Given the recent calls to have a more consistent definition for corporate reputation, it was important to identify the clusters for defining corporate reputation. Barnett et al. (2006) categorized the definitions of corporate reputation into three main clusters:

(1) reputation as a state of awareness

(2) reputation as an assessment 
(3)

reputation as an asset

For those definitions that consider reputation as state of awareness, the single most commonly used term for defining corporate reputation in this cluster is "perceptions." Within this cluster, corporate reputation is defined as: "an aggregation of perceptions", "latent perceptions," "net perceptions," "global perceptions," "perceptual representations" and "collective representations." This cluster also includes references to corporate reputation as "representations of knowledge or emotions" since they reflect awareness about a firm.

The most common form for defining corporate reputation was those that consider reputation as an assessment. Those definitions referred to corporate reputation as an assessment of the status of a firm. This includes references to corporate reputation as a "judgment," an "estimate," an "evaluation" or a "gauge." Aspects about the "opinions" and "beliefs" about an organization also fit into this cluster because they reflect the subjective nature of reputation.

The third cluster, reputation as an asset, incorporates those definitions that refer to reputation as something of value and significance to the firm. This group includes references to reputation as a "resource" or as an "intangible, financial or economic asset." Definitions that describe reputation as "awareness" or as an "assessment" do not consider that a firm's reputation has real value to an organization. Many have debated this cluster of meaning by proposing that this is more related to the consequences of reputation, than of the meaning of reputation itself.

Walker (2010) divided corporate reputation definitions into 5 groups: (1) perceptual definitions which focus on defining corporate reputation as stakeholder's viewpoints about the overall perceptions regarding both internal and external aspects about an organization, (2) aggregate definitions which is a collective perspective which is based on the perceptions of all stakeholder groups about an organization, (3) comparative definitions which compares reputation to other competitors in the market, (4) positive or negative definitions which means that reputation can be either positive or negative, and (5) temporal definitions which means that reputations are time-specific and can change over time (Gray and Balmer 1998, Mahon 2002, Rhee and Haunschild 2006).

These different clusters highlight the importance of understanding the meaning of reputation and the context in which it is presented. This also raises the importance of having an integrated view about corporate reputation.

\subsection{Toward an Integrated View of Corporate Reputation}

Due to the nature of corporate reputation as a comprehensive and collective construct, many scholars have thought of corporate reputation as being the integration or summation of other corporate-related concepts. Brown et al. (2006) perceive that corporate reputation is the external stakeholder's perceptions about an organization (Refer to Figure 2).

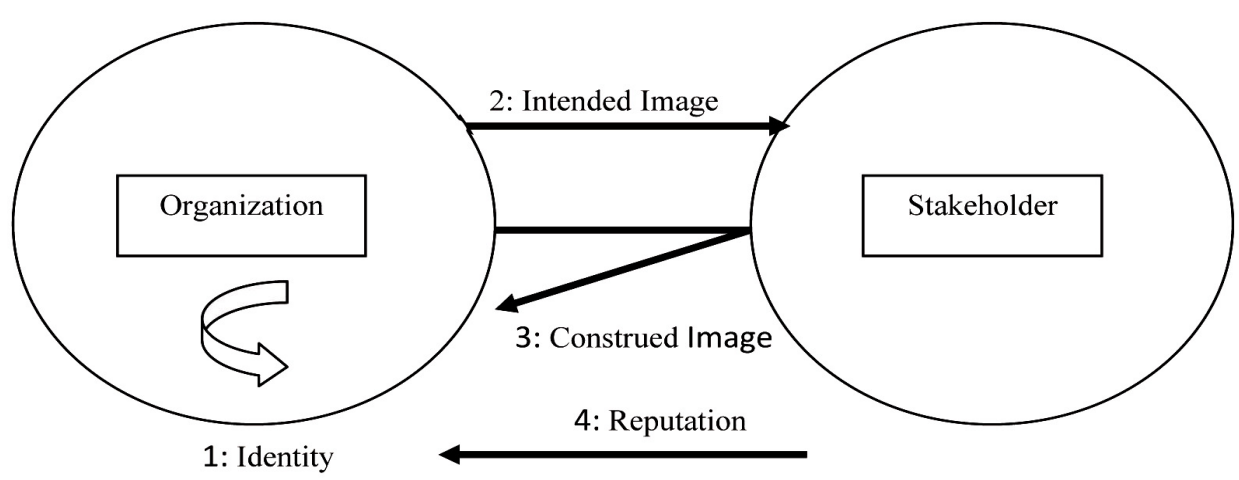

Figure 2. Key organizational viewpoints

Source: Brown, Tom, Peter Dacin, Michael Pratt and David Whetten (2006).

Fombrun (1996) pictures corporate reputation as a function of corporate identity and corporate image. Refer to Figure 2 below. The starting point of corporate reputation is corporate identity, which are internal stakeholders perceptions about an organization. Corporate image is formed through the companies branding and communication activities to the external stakeholder groups. Collectively, all images developed by different stakeholder groups whether customers, community, investor and employees (these are images created from external branding and communication activities) form corporate reputation. 


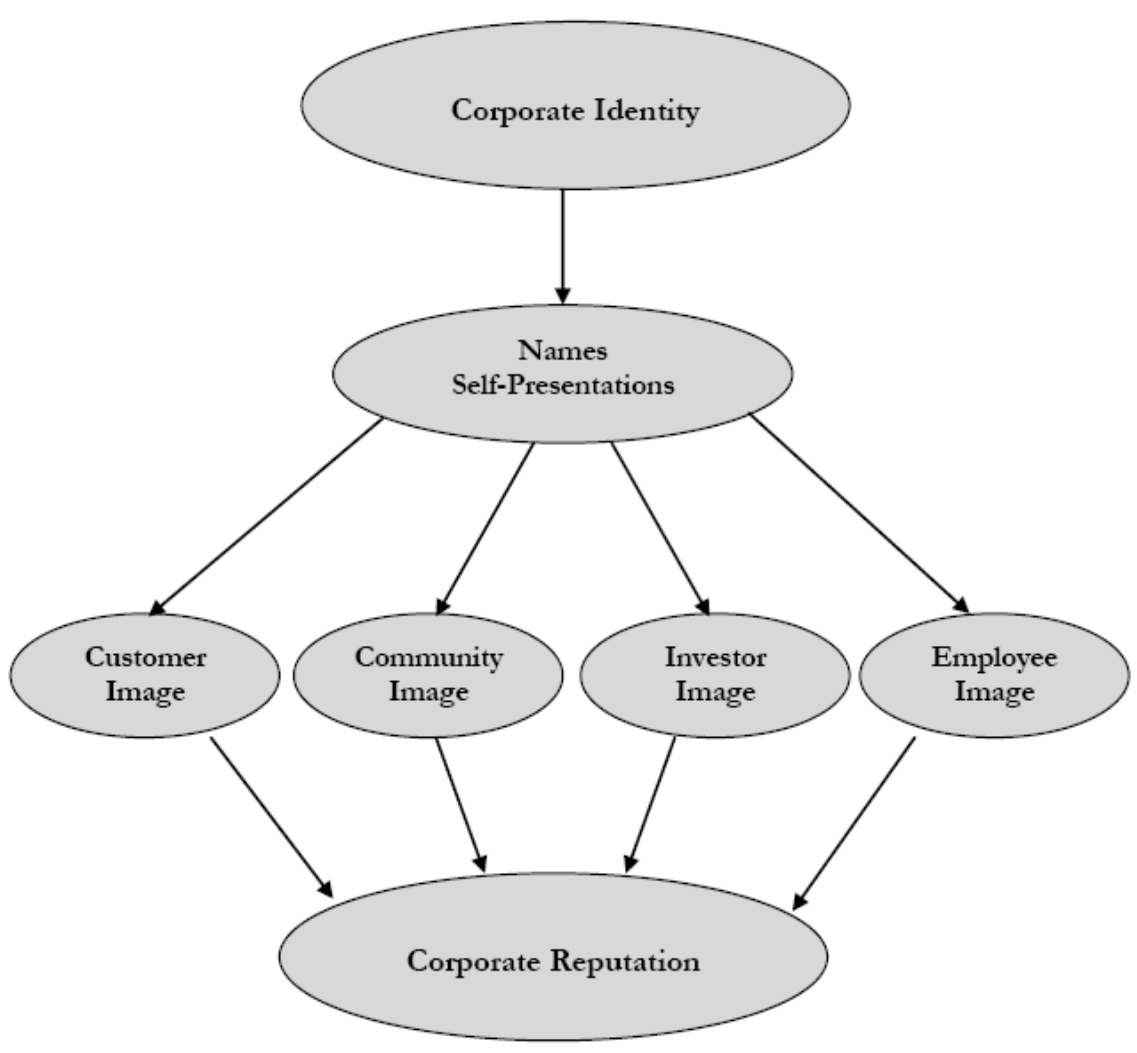

Figure 3. From identity to reputation

Source: Fombrun, 1996.

Due to the interdependency of reputation on many factors such as personal reputation, industry reputation, competitor reputation, country reputation and other environmental factors, it is important to consider the external and internal factors when examining reputation. For example, a firm's reputation can be affected by other firm's within or outside the industry. Further, a firm's reputation can be affected by aspects that are beyond its own history and include intra-industry and inter-industry effects. Refer to Figure 4 below.

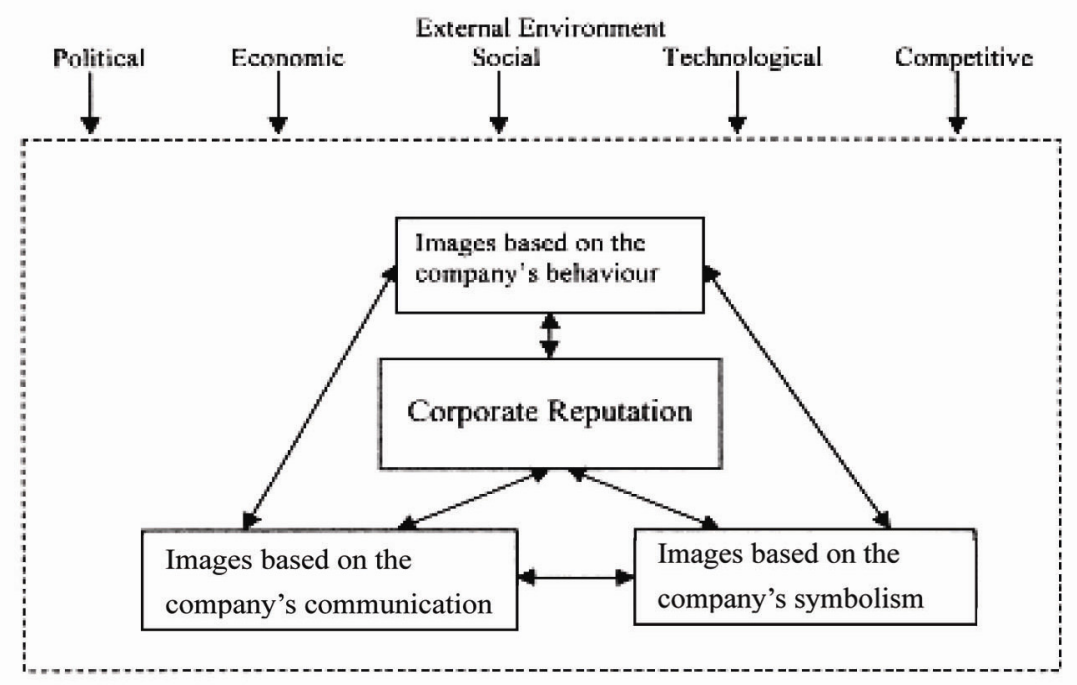

Figure 4. Defining corporate reputation

Source: Gotsi and Wilson (2001) 
Figure 4 above highlights that images based on: company behavior, company symbolism and company communication form the reputation of companies. It also highlights that reputation is affected by environmental factors such as: political, economic, social, technological and competitive factors.

Many definitions for corporate reputation suggest that corporate image and corporate identity together form corporate reputation. This definition is in line with other suggestions that view reputation as an aggregation of other corporate-based measures such as identity, image, branding, and communications. Wartick (2002) proposes the following:

$$
\text { Reputation }=f(\text { Image }+ \text { Identity })
$$

Doorley and Garcia (2007) highlight the importance of managing all elements of reputation. They define reputation as:

$$
\text { Reputation }=\text { Sum of Images }=(\text { Performance }+ \text { Behavior })+\text { Communication }
$$

Barnett, Jermier and Lafferty (2006) disaggregate corporate reputation into its different components. Refer to Figure 5. The starting point for corporate reputation is corporate identity, which reflects the character of the firm reflected in the internal culture and values of the firm. Corporate identity is thought of as a collection of symbols derived from internal values and beliefs. This then leads to the formation of corporate images which is created through corporate communication, corporate branding, corporate visuals. This results in the formation of impressions about the firm. The formation of judgments by observers is the reflection of a company's reputation. Ultimately, this results in corporate reputation capital which is an economic and intangible asset which companies strive to achieve.

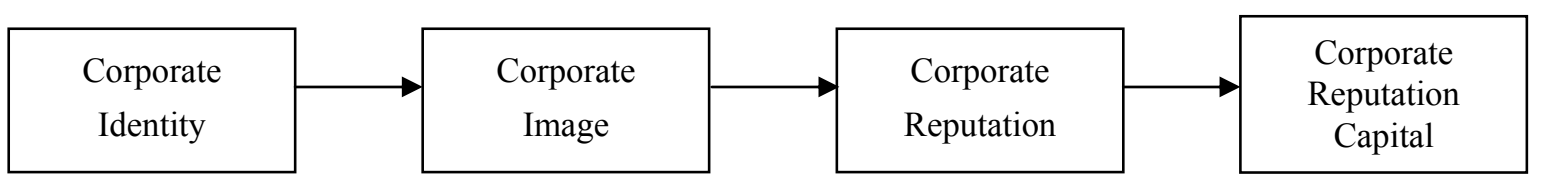

Figure 5. Disaggregating corporate reputation

Collection of symbols Impressions of the firms Judgment by observers Economic asset

Source: Barnett, Jermier and Lafferty (2006)

\subsection{Factors Affecting Corporate Reputation}

It has been cited in the literature, that corporate reputation is affected by many factors. Personal reputation affects corporate reputation (Bromley 2001; Musteen et al., 2009). The reputation of the leader, management or the owner affects the reputation of an organization. Many studies have highlighted the importance of the leader's reputation in determining the reputation of an organization to the extent that the leader can account for up to $48 \%$ of the organization's reputation (Klein, 1999; Grupp and Gaines-Ross, 2002). This was clearly the case for many organizations such as Apple, General Electric. Accordingly, Klein (1999) and Grupp and Gaines-Ross (2002) emphasize the importance of managing the leaders reputation in terms of: credibility, integrity, and high quality communications.

Industry reputation also affects corporate reputation. In most cases this is the result of the work of a few organizations which affect all organizations within the industry. This is beneficial for those organizations that are not competitive enough which gain from a good industry reputation (Mahon 2002). Finally, the reputation of a country also affects corporate reputation. This includes the effect of country-of-origin on the reputation of corporations (Mahon, 2002).

Reputations are self-validating in the sense that beliefs derived from one source are confirmed by other sources. This evaluation could be based on stakeholder's direct experiences with a company and other forms of communication and symbols from a company from other people and objects. Further, it is formed over time by repeated impressions of the corporate image whether positive or negative (Gray and Balmer, 1997; 1998; Alessandri 2001).

Other elements that have been cited to affect corporate reputation include:

1) Organizational ethics

2) Financial performance 
3) Shareholder value

4) Corporate branding activities

5) Marketing mix activities

6) Public relations

7) Relationships with stakeholders (Le Roux, 2003)

\subsection{Which Stakeholder Perception?}

The literature contains many views about which stakeholder perspective to take into account when examining corporate reputation. Examples include: customer-based corporate reputation (e.g. Brown and Dacin, 1997; Caruana and Chircop, 2000; Davies et al., 2001, employee-based corporate reputation (e.g. Albinger and Freeman, 2000; Turban and Greening, 1997) public-based reputation (e.g. Handelman and Arnold, 1999, Shamma and Hassan (2009), investor-based reputation (e.g. Clark-Murphy and Soutar, 2004; Helm, 2007), and many others. These different points of view are derived from the interest of the researcher and reflect the wide effects of reputation on diverse stakeholder groups.

There is one group of studies that focus on measuring corporate reputation from a specific stakeholder group perspective, for example, consumers (Brown and Dacin, 1997; Davies et al., 2001), employees (e.g. Albinger and Freeman 2000), investors (Helm 2007b) and society, (e.g Handelman and Arnold, 1999). In line with this point of view is Puncheva-Michelotti and Michelotti's (2010) stakeholder-specific approach, where different reputation dimensions are examined from a specific stakeholder perspective. This group of studies proposes that corporate reputation should be stakeholder-specific measures that relate to specific stakeholder groups. For example, if corporate reputation was measured from a customer perspective, dimensions such as products and services, advertising claims and corporate social responsibility would be measured (Caruana and Chircop 2000). If employees' perspective was examined, dimensions such as employee relations, community relations, treatment of women and minorities would be relevant measures (Turban and Greening, 1996). From a general public perspective, dimensions such as corporate social responsibility would be relevant (Handelman and Arnold, 1999). Proponents of the stakeholder-specific measure believe that each stakeholder group has its own dimensions that are relevant and shape the interest in this stakeholder group.

The second group of studies proposes a more generic approach for measuring corporate reputation. This group proposes a more standard approach for measuring corporate reputation that applies across all stakeholder groups. Well known measures such as the Reputation Quotient (Fombrun et al., 2000), corporate personality scale (Davies et al., 2001) use a generic measure that can be examined across multiple stakeholder groups. This group believes that corporate reputation should be a generic measure that should be reflective of reputation. Different stakeholders should be able to reflect on the different dimensions of corporate reputation although they may not have a direct experience with these dimensions.

The proponents of the general measure believe that reputation is a general construct that should be generally applied to all different stakeholder groups. The reason is that it is more pragmatic and easier for measurement purposes (Wartick, 2002).

It is proposed that both the stakeholder-specific and general perspective about reputation are both valid for assessing reputation. If the objective is to assess perspective of a specific stakeholder group, then stakeholder-specific measures are appropriate. If the objective is to assess the perspective of the general public or the society in general, then the generic measure would be more appropriate. The stakeholder-specific and the general perspective are not contradictory measures. Rather, they are complementary approaches and the selection of the approach highly depends on the research objectives.

\subsection{How are Reputations Formed?}

Reputations about companies can be based on a variety of sources. Some stakeholders may rely on direct experience they have with an organization in the form of a company's products and services, shops and employees. Others may rely on other indirect sources to form their perceptions about corporate reputation. Following are a list of different sources for corporate reputation formation:

- The employees' behavior and communication;

- Individuals' experiences with the company;

- Company's self-presentations;

- Media interpretations of the company; 
- Word of mouth;

- Competitors;

- Rumors (Caruana, 1997; Dowling 2001; Cravens, Oliver and Ramamoorti, 2003).

Fombrun (1996) has identified six inputs to building corporate reputation: (1) information from the organization; (2) audit data; (3) investment analysis; (4) journalistic insights; (5) hearsay/rumor; (6) brand activities (customer image, community image, investor image, employee image).

\section{Antecedents and Consequences of Corporate Reputation}

Many studies have been conducted to study the antecedents and consequences of corporate reputation formation. There are two approaches for examining the antecedents and the consequences of corporate. The first is the strategic approach; the second is the stakeholder approach.

The strategic approach examines the corporate resources and capabilities required to achieve a positive reputation and the impact of a positive reputation on company performance (Refer to Table 1). It is thought that companies which are large in size (billings and employees), have visible corporate social responsibility activities, and have high media expenditures, result in a more favorable corporate reputation than their counterparts (Carmeli and Tischler 2005; Rao 1994; Fombrun and Shanley 1990). It is believed that the consequences of such behavior will be reflected in superior corporate performance (Wilson 1985). Further, a number of studies have highlighted the consequences of a positive corporate reputation and its ability to enable a corporation to charge premium prices, attract capital, attract employees and increase customers' purchase intentions (e.g. Rao 1994).

Table 1. Antecedents and consequences of corporate reputation: strategic and stakeholder perspective

\begin{tabular}{lccc}
\hline & Antecedents & $\begin{array}{c}\text { Attitudinal } \\
\text { Corporate Reputation }\end{array}$ & $\begin{array}{c}\text { Behavioral } \\
\text { Consequences }\end{array}$ \\
\hline Strategic Level & Asset Generating & Intangible Assets & Market \\
& Activities & Assets/Performance \\
Stakeholder Level & Experience/Observation & Belief/Attitudes & Intentions/Behaviors \\
\hline
\end{tabular}

Source: Money and Hillenbrand (2006).

Brown (1998) postulated that there were four key antecedents of corporate associations: (1) characteristics of the company's products and services, (2) corporate communication, (3) third party communication, (4) general business stereotype; and two main consequences: (1) product responses, and (2) responses to the company. Fombrun and Shanley (1990) stated that profitability, advertising expenditure, firm size, ownership and charity positively affect reputation. Other studies purported that firm size, media exposure, financial performance and charity enhanced a firm's reputation. Wartick (1992) linked media intensity with positive firm reputation.

Other studies addressed the strategic impact of corporate reputation on a firm's overall operations and performance. Carmeli and Tischler (2005) highlighted the mediating role of customer satisfaction in the relationship between the quality of goods and services and organizational reputation. They also addressed the effect of organizational reputation on a firm's market share and profitability.

Furthermore, several studies have demonstrated the link between corporate reputation and barriers to entry, access to capital and overall business continuity and survival (Rao 1994; Beatty and Ritter 1986; Wilson 1985). Also positive corporate reputation has been identified as a signal for a firm to charge premium prices, attract and retain customers and attract qualified employees (Rao 1994). A summary of the studies that assessed the antecedents and consequences of corporate reputation from a strategic perspective is presented in Table 2 . 
Table 2. Studies on antecedents and consequences of corporate reputation: a strategic perspective

\begin{tabular}{|c|c|c|}
\hline Study & Antecedents & Consequences \\
\hline & Profitability & \\
\hline \multirow[t]{4}{*}{ Fombrun and Shanely (1990) } & Advertising expenditure & \\
\hline & Firm size & \\
\hline & Ownership & \\
\hline & Charity & \\
\hline Barney (1991) & Quality of inputs & \\
\hline Wartick (1992) & Media Intensity & \\
\hline Stuart et al. (1999) & Affiliation with high status actors & \\
\hline Rindova and Kotha (2001) & Personality-driven revenues & \\
\hline Brammer and Millington (2005) & Philanthropic expenditures & \\
\hline \multirow[t]{3}{*}{ Beatty and Ritter (1986) } & & Access to capital \\
\hline & & Long term business continuity \\
\hline & & Charge premium prices \\
\hline \multirow[t]{3}{*}{ Rao (1994) } & & Attract and retain customers \\
\hline & & Attract qualified employees \\
\hline & & Charge premium prices \\
\hline Fombrun (1996) & & Economies of promotional costs \\
\hline Weiss et al. (1999) & & Supplier choice \\
\hline $\begin{array}{c}\text { Brown and Dacin (1997); Vendelo } \\
\text { (1998) }\end{array}$ & & Evaluation of new products \\
\hline \multicolumn{3}{|l|}{$\begin{array}{l}\text { Andreassen and Lindestad (1998); } \\
\text { Nguyen and Leblanc (1998) }\end{array}$} \\
\hline Bennett and Gabriel (2001) & & Suppliers loyalty \\
\hline Handelman and Arnold (1999) & & Community support \\
\hline $\begin{array}{l}\text { Ind (1997); Nakra (2000); } \\
\text { Dowling (2001) }\end{array}$ & & $\begin{array}{l}\text { Favorable stakeholder } \\
\text { relationships }\end{array}$ \\
\hline \multirow{4}{*}{ Brown (1998) } & $\begin{array}{c}\text { Characteristics of products and } \\
\text { services }\end{array}$ & Product response \\
\hline & Corporate communication & Response to the company \\
\hline & Third party communication & \\
\hline & General business stereotype & \\
\hline Little and Little (2000) & Social responsibility & Price-earnings ratio \\
\hline \multirow[t]{2}{*}{ Carmeli and Tischler (2005) } & Quality of goods and services & Market share \\
\hline & & Profitability \\
\hline
\end{tabular}

Assessing antecedents and consequences of corporate reputation at the strategic level will enable a firm to improve the management of its resources to reach its corporate goals and objectives. However, a firm would also benefit from understanding its relationship with its various stakeholders, and thus the need arises to assess the antecedents and consequences of corporate reputation at the individual stakeholder level. The following section presents a framework that addresses the stakeholder-level antecedents and consequences of corporate reputation.

Examining corporate reputation at the stakeholder level is important in order to have a better understanding about how stakeholders form perceptions about the reputations of companies and accordingly develop behavioral 
intentions and behavioral outcomes toward those companies. There are various models that can be utilized to get a better understanding of reputation at the stakeholder level. Some of these models include: the theory of reasoned action, (Fishbein and Ajzen, 1975), the theory of planned behavior (Ajzen and Fishbein 1980), the tripartite model of attitude (Rosenberg and Hoyland 1980), the hierarchy of effects model (Lavidge, 1961).

The stakeholder approach highlights the need to examine the drivers that lead stakeholders to form attitudes about corporations which in turn lead to behavioral intentions and actual behavior (Refer to Table 1). Caruana et al. (2006) studied the relationship between corporate reputation and shareholders' behavioral intentions. In their study Caruana, et al. (2006) studied the effect of corporate reputation on shareholders' intentions to invest in a corporation. Aspara and Tikkanen (2011) proved that a person's identification with a company positively affects their intentions to invest in a company's shares. Shamma and Hassan (2009) examined customers and non-customers formation of perceptions about corporate reputation and consequently behavioral intentions toward organizations. Ressler and Abratt (2009) provided evidence to support the positive relationship between university and stakeholder's intentions. The stakeholders examined were: prospective students, current students, alumni and employers.

\section{Measuring Corporate Reputation}

\subsection{Measuring Corporate Reputation - Practitioners Viewpoint}

Practitioners were the first to propose ways to measure corporate reputation as they sought tools for evaluating perceptions about corporations. Practitioners presented several methods that assess individuals' perceptions about corporations. Following are the highlights of some of these methods:

Fortune magazine developed a survey instrument where financial analysts and executives are asked to rate companies based on the following eight characteristics: (1) financial soundness, (2) value as a long-term investment, (3) wise use of corporate assets, (4) innovativeness, (5) ability to attract, develop and keep talented people, (6) quality of products and services, (7) quality of management, and (8) community and environment responsibility (Sobol et al. 1992). This survey format is still used to determine the ranking of Fortune's America's Most Admired Corporations.

Corebrand, a consulting firm, developed the Corporate Branding Index to assess the impact of corporate branding on financial performance. The index provided an indication to management about its return on investment from corporate advertising (Corebrand 2005). The Wall Street Journal also asks respondents regarding their perceptions about reputation, management quality and investment potential of hundreds of companies.

It is also interesting to note, that recently other companies have joined the league for reputation ranking. Rating research is an institution that rates companies and assigns letter grades, just like Moody's grades from AAA to C. These letter assignments are "a long-term assessment of a companies ability to pay its debt," says Jefffrey Resnick, Chief Research Officer at Rating Research.

While the measures developed by practitioners are useful for assessing corporate reputation, they have a variety of drawbacks: First, these measures assess corporate perceptions based on one group of stakeholders, mainly, financial analysts and investors. Thus, the results could be biased because the perspectives of other stakeholders are not adequately considered. Second, the measures were not tested for validity and reliability. Given these drawbacks, scholars were motivated to identify better measures for corporate reputation.

\subsection{Measuring Corporate Reputation - Academic Viewpoint}

Academic studies on measuring corporate reputation can be generally classified into: (1) single-faceted generic measures of corporate reputation, and (2) multi-faceted specific measures of corporate reputation. In the case of single-faceted generic measures, all stakeholders are asked generic questions regarding their perceptions about the overall reputation of a corporation. For example, Wang et al. (2006) presented a generic measure of corporate reputation by assessing: (1) overall perceptions of experience with a firm, (2) perceptions against other competitors, and (3) perceptions about the future of the firm. Gardberg and Hartwick (1990) assessed company reputation by examining perceptions about a company's relations with its employees, financial investors, U.S. public and Canadian public.

However, researchers realized that using a single-overall measure for corporate reputation did not incorporate the specific measures by which stakeholders form their overall perception of a corporations' reputation. Moreover, using single-item measurement limits the organization's ability to identify the specific elements of a corporation which bring about a positive reputation and which elements result in a negative reputation. Thus, a series of measures for corporate reputation have been proposed from a multi-specific approach. 
A series of measures have been proposed that measure corporate reputation from a multi-faceted perspective. The most popular measure for corporate reputation was that developed by Fombrun et al. (2000). Fombrun et al. (2000) developed the Reputation Quotient (RQ), a multi-dimensional construct composed of six dimensions that identified the stakeholders' perceptions about the reputation of a company. These dimensions include the following: (1) emotional appeal, (2) products and services, (3) vision and leadership, (4) social and environment responsibility, (5) workplace environment, and (6) financial performance.

Also, Helm (2005) developed a similar measure for corporate reputation that was composed of ten elements: (1) quality of products, (2) commitment to protecting the environment, (3) corporate success, (4) treatment of employees, (5) customer orientation, (6) commitment to charitable and social issues, (7) value for money of products, (8) financial performance, (9) qualification of management, and (10) credibility of advertising claims. This highlights the growing importance of measuring corporate reputation from a multi-faceted perspective as opposed to a single-faceted perspective.

Fombrun (2007) developed a "list of lists" of the various reputation rankings across the world. This list provides examples of the different entities that did rankings related to reputation by country. Fombrun (2007) identified rankings done in 37 different countries as well as regional and global rankings. The list also highlights that we have to understand the basis of these rankings and the underlying methodology as they all have different dimensions, criteria and accordingly different rankings.

Recently, Ponzi et al. (2011) proposed a short form of the reputation scale (RepTrak Pulse), an emotion based scale that differentiates between the drivers of corporate reputation and the construct itself. Through a series of some in-depth interviews, it was found that: (1) company feeling, (2) admire and respect, (3) company confidence and (4) overall reputation to be the dimensions for reputation. The data was cross-checked for validity and reliability and was deemed acceptable. This shorter form of the RepTrak Pulse is thought to facilitate cross-cultural research on reputation and will help simplify collecting survey-based data (Ponzi et al, 2011).

Among the various measures for corporate reputation, the Reputation Quotient remains to be the most popular measure. It was one of the first measures for reputation and many subsequent measures for reputation are based on the Reputation Quotient. Wartick (2002) claims that the Reputation Quotient is a good measure for reputation as it is broad and generic enough that makes it applicable to most stakeholder groups and many cultural contexts.

Groenland (2002) highlighted that the Reputation Quotient satisfies the psychometric properties, and the practical experience in many different commercial settings. This increases the confidence in the usefulness of the Reputation Quotient. The results of Groenland's (2002) qualitative study to validate the dimensions of the Reputation Quotient highlighted that all six dimensions of the Reputation Quotient were supported as relevant for measuring corporate reputation.

The Corporate Character scale is another common scale used to assess corporate perceptions. It has been found that both the Reputation Quotient and the Corporate Character scale to be valid in various international contexts (e.g. Chettamrongchai, 2010 in Thailand among others).

Groenland (2002) highlighted the importance of being open to other dimensions when measuring corporate reputation. Cultural differences are always important to consider when measuring corporate reputation. It has been identified that there could be culture-specific dimensions of reputation that have to be considered when studying corporate reputation in different cultural contexts. For example, it was found that national origin and charismatic representatives should be added when applying reputation in Deutschland. This suggests that corporate reputation should be adapted to specific local cultures, and thus qualitative research is recommended before applying a standard approach to identify any culture-specific dimensions.

\section{Managerial Implications}

There is evidence of increased interest in reputation management. The growing anti-business virulence are posing new strategic risks for corporations (Kartalia, 2000). The increased globalization of the marketplace and the instant information exchange, are reasons for the increased importance of managing a company's reputation. Practitioners are realizing that they can no longer wait to react when they are faced with a reputation crisis. Companies should proactively seek ways to enhance the reputation of firms. It should not be seen as only a tool that safeguards companies during turbulent times, but as a strategic approach for sustaining a company during its lifetime. This would help companies achieve a strategic competitive advantage that would sustain a business on the long-term.

The questions that many senior managers are puzzled with are:

- Where do we start with in managing corporate reputation? 
- Are all elements of corporate reputation of equal importance?

- Are there primary and secondary elements of the corporate reputation dimensions?

- What elements should a manager focus on?

This aspect about corporate reputation management has not gained much attention in the literature. Few research studies have examined the pillars for corporate reputation management and provided managerial recommendations for corporate reputation management. Shamma and Hassan (2009) highlight that there are primary and secondary pillars for corporate reputation management. Workplace environment and products and services were identified to be the two main primary pillars for corporate reputation management (Shamma and Hassan, 2009). These elements of corporate reputation are the core elements that need to be managed first, as they are the ones that greatly affect corporate reputation. Thus, managers should identify ways to improve perceptions about workplace environment and perceptions about products and services of an organization. Financial performance, vision and leadership, emotional appeal and environmental responsibility represent the secondary pillars of corporate reputation. These secondary pillars need to be managed once the primary elements are properly managed. The primary and secondary pillars can be presented in the below pyramid (See Figure 6 below):

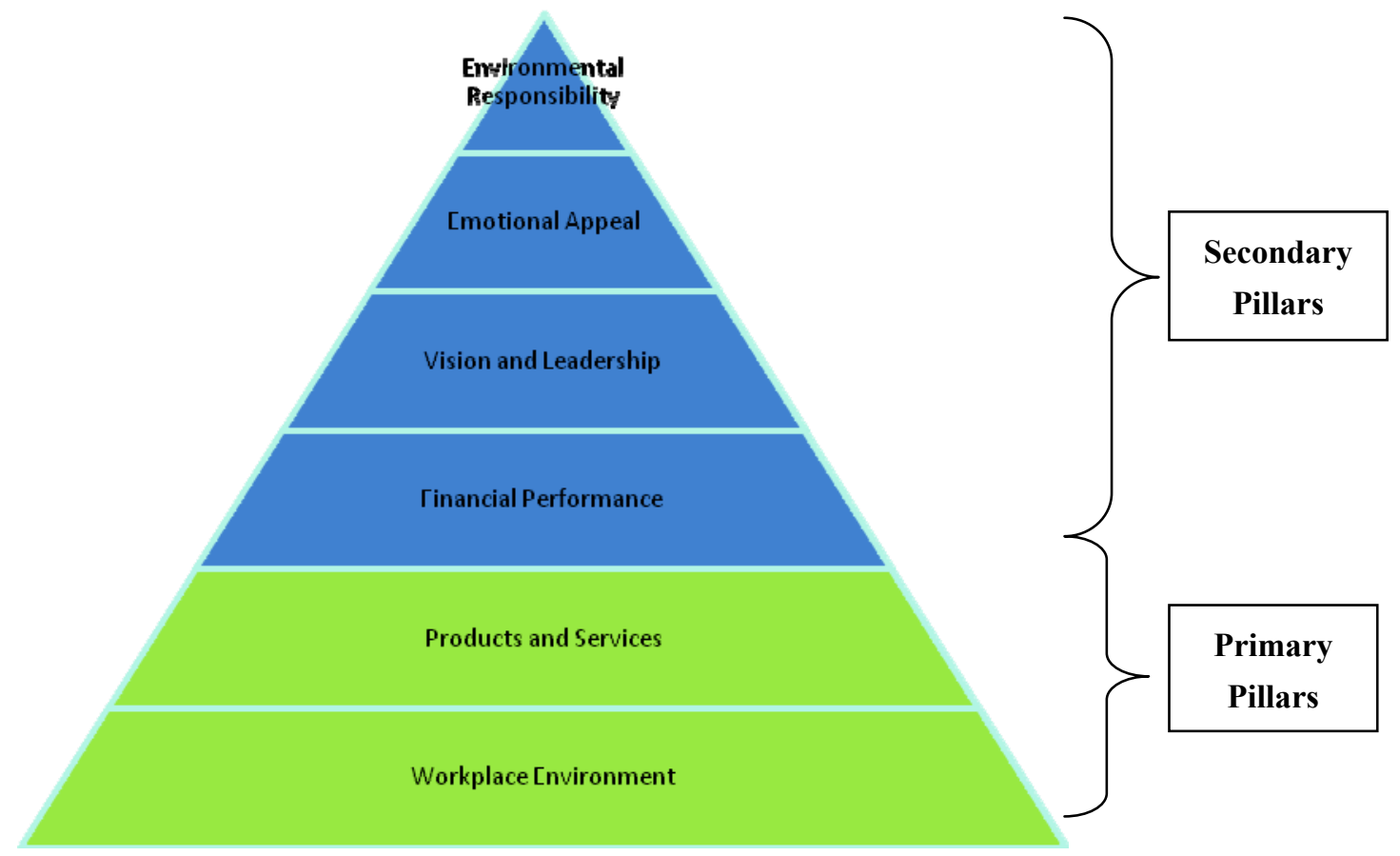

Figure 6. Pyramid-based pillars for corporate reputation

Another issue that is raised in corporate reputation management is, who is responsible for corporate reputation management? Is this the role of:

- Corporate Communications Manager

- Corporate Reputation Manager

\section{- $\quad$ Chief Executive Officer}

It is advised that companies hire managers that have the Corporate Reputation Manager title. They will have responsibility for developing a corporate reputation strategy and implementing this strategy. The implementation can be done with the help of the corporate communications manager. The corporate communications manager will provide the various corporate communication tools to execute the corporate reputation strategy. Finally, the chief executive officer should oversee the work done by the corporate reputation manager and the corporate communication manager to make sure they are aligned and follow the strategic direction and mission of the organization. 


\section{Conclusion}

This paper attempted to advance our understanding about corporate reputation which is becoming increasingly important in today's highly turbulent, dynamic and demanding business environment. This was done by: highlighting the importance of reputation as a strategic intangible asset; defining corporate reputation, identifying clusters for corporate reputation and differentiating corporate reputation among other corporate-related concepts within the corporate marketing landscape; identifying the factors affecting reputation; presenting the different forms for measuring corporate reputation; analyzing the antecedents and consequences of corporate reputation from the strategic and stakeholder perspective; and finally presenting some aspects about the managerial implications of corporate reputation.

Corporate reputation should be given more attention from the practical side. While, we are seeing more attention given from the academic side, evidenced by significant increase in the number of academic papers and articles, yet we are not realizing equal attention given from the business side. It is suggested that more research to be conducted to highlight the effect of reputation on firm performance and sustainability. More case studies should be done to highlight reputation as an important strategic asset especially during challenging and turbulent times. These cases should highlight examples of successful companies that actively manage reputation and the consequences of their actions on their sustainability, competitiveness and at times of crises. There should be also cases of companies that did not actively manage their reputation and examine their effects on company performance, sustainability and at times of crises. These cases will highlight the need for corporate reputation management and will highlight the need for hiring corporate reputation managers to manage, organize and implement corporate reputation strategies and plans.

\section{References}

Ajzen, I., \& Fishbein, M. (1980). Understanding Attitudes and Predicting Social Behavior. Englewood Cliffs, New Jersey: Prentice-Hall.

Albert, S., \& Wetten, D. A. (1985). Organizational Identity. In L. L. Cummings \& B. M. Staw (Eds.), Research in Organizational behavior (Vol. 7). Greenwich, Conn: JAI Press.

Albinger, H.S., \& Freeman, S. (2000). Corporate Social Performance and Attractiveness as an Employer to Different Job Seeking Populations. Journal of Business Ethics, 28(3), 243-253. http://dx.doi.org/10.1023/A:1006289817941

Alessandri, S. W. (2001). Modelling corporate identity: a concept explication and theoretical explanation. Corporate Communications: An International Journal, 6(4), 173-182. http://dx.doi.org/10.1108/EUM0000000006146

Andreassen, T. W., \& Lindestad, B. (1998). Customer loyalty and complex services: The impact of corporate image on quality, customer satisfaction and loyalty for customers with varying degrees of service expertise. $\begin{array}{lllll}\text { International Journal of Service Industry Management, } & 9(1), & \text { 7-23. }\end{array}$ http://dx.doi.org/10.1108/09564239810199923

Balmer, J. M. T. (2001). Corporate Identity, Corporate Branding and Corporate Marketing: Seeing Through the Fog. European Journal of Marketing, 35(3/4), 248-291. http://dx.doi.org/10.1108/03090560110694763

Balmer, J., \& Greyser S. (2003). Revealing the Corporation: Perspectives on Identity, Image, Reputation, Corporate Branding and Corporate-Level Marketing. London: Routledge.

Balmer, J. M. T. (2001). From the Pentagon: a new identity framework. Corporate Reputation Review, 4(1), 11-22. http://dx.doi.org/10.1057/palgrave.crr.1540129

Barnett, M., Jermier, J., \& Lafferty, B. (2006). Corporate Reputation: The Definitional Landscape. Corporate Reputation Review, 9(1), 26-38. http://dx.doi.org/10.1057/palgrave.crr.1550012

Barney, J. (1991). Firm Resources and Sustained Competitive Advantage. Journal of Management, 17(1), 99-121. http://dx.doi.org/10.1177/014920639101700108

Beatty, R. P., \& Ritter J. R. (1986). Investment banking, reputation, and underpricing of initial public offerings. Journal of Financial Economics, 15, 213-232. http://dx.doi.org/10.1016/0304-405X(86)90055-3

Bennett, R., \& Gabriel, H. (2001). Reputation, trust and supplier commitment: the case of shipping company/seaport relations. The Journal of Business and Industrial Marketing, 16(6), 424-438. http://dx.doi.org/10.1108/EUM0000000006018 
Berens, G., \& Van Riel, C. B. M. (2004). Corporate Associations in the Academic Literature: Three Main Streams of Thought in the Reputation Management Literature. Corporate Reputation Review, 7(2), 161-178. http://dx.doi.org/10.1057/palgrave.crr.1540218

Bick, G., Jacobson, M. C., \& Abratt, R. (2003). The corporate identity management process revisited. Journal of Marketing Management, 19, 835-55.

Boyd, B. K., Bergh, D. D., \& Ketchen Jr. D. J. (2010). Reconsidering the Reputation-Performance Relationship: A Resource-Based View. Journal of Management, 36(3), 588-609. http://dx.doi.org/10.1177/0149206308328507

Brammer, S., \& Millington, A. (2005). Corporate Reputation and Philanthropy. Journal of Business Ethics, 61(1), 29-44. http://dx.doi.org/10.1007/s10551-005-7443-4

Bromley, D. B. (2001). Relationships between personal and corporate reputation. European Journal of Marketing, 35(3/4), 316-334. http://dx.doi.org/10.1108/03090560110382048

Brown, T. J., \& Dacin, P. A. (1997). The company and the product: corporate associations and consumer product responses. Journal of Marketing, 61(1), 68-84. http://dx.doi.org/10.2307/1252190

Brown, T. (1998). Corporate Associations in Marketing: Antecedents and Consequences. Corporate Reputation Review, 1(3), 215-233. http://dx.doi.org/10.1057/palgrave.crr.1540045

Brown, T. J., Dacin, P. A., Pratt, M. G., \& Whetton, D. A. (2006). Identity, intended image, construed image and reputation: An interdisciplinary framework and suggested terminology. Journal of the Academy of Marketing Science, 34(2), 99-106. http://dx.doi.org/10.1177/0092070305284969

Buffet, W. (2009). US Entrepreneur and Financier. Independent, London, October 28.

Bullmore, J. (1984). The Brand and Its Image Revisited. International Journal of Advertising, 1(3), 235-38.

Burt, S., \& Sparks, L. (2002). Corporate branding, retailing, and retail internationalization. Corporate Communications, 5(2/3), 194-212.

Carmeli, A., \& Tischler, A. (2005). Perceived Organizational Reputation and Organizational Performance: An Empirical Investigation of Industrial Enterprises. Corporate Reputation Review, 8(1), 13-30. http://dx.doi.org/10.1057/palgrave.crr.1540236

Caruana, A. (1997). Corporate reputation: concept and measurement. Journal of Product and Brand Management, 6(2), 109-18. http://dx.doi.org/10.1108/10610429710175646

Caruana, A., Cohen, C., \& Krentler, K. (2006). Corporate Reputation and Shareholders Intentions: An Attitudinal Perspective. Journal of Product and Brand Management, 13(6), 429-440.

Caruana, A., \& Chircop, S. (2000). Measuring Corporate Reputation: A case example. Corporate Reputation Review, 3(1), 43-57. http://dx.doi.org/10.1057/palgrave.crr.1540098

Chettamronchai, P. (2010). Revalidating Two Measures of Reputation in Thailand. Corporate Reputation Review, 13(3), 209-219. http://dx.doi.org/10.1057/crr.2010.17

Chun, R. (2005). Corporate reputation: Meaning and measurement. International Journal of Management Review, 7(2), 91-109. http://dx.doi.org/10.1111/j.1468-2370.2005.00109.x

Clark-Murphy, M., \& Soutar, G. N. (2004). What Individual Investors Value: Some Australian Evidence. Journal of Economic Psychology, 25(4), 539-555. http://dx.doi.org/10.1016/S0167-4870(03)00056-4

Corebrand, (2005). Our Services. Retrieved from http://www.corebrand.com/services/services.html

Cravens, K., Oliver, E. G., \& Ramamoorti, S. (2003). The reputation index: Measuring and managing corporate $\begin{array}{llll}\text { reputation. } \quad \text { European } & \text { Management 21(2), }\end{array}$ http://dx.doi.org/10.1016/S0263-2373(03)00015-X

Davies, G., Chun, R., Silva, D. R. V., \& Roper, S. (2003). Corporate Reputation and Competitiveness. Trowbridge, Wiltshire: The Cromwell Press. http://dx.doi.org/10.4324/9780203218112

Davies, G., Chun, R., Silva, R. V. D., \& Roper, S. (2001). The personification metaphor as a measurement approach for corporate reputation. Corporate Reputation Review, 4(2), 113-127. http://dx.doi.org/10.1057/palgrave.crr.1540137

Davies, G., \& Miles, L. (1998). Reputation Management: Theory versus Practice. Corporate Reputation Review, 2(1), 16-28. http://dx.doi.org/10.1057/palgrave.crr.1540064 
De Chernatony, L. (1999). Brand management through narrowing the gap between brand identity and brand $\begin{array}{lllll}\text { reputation. Journal of } & \text { Marketing }\end{array}$ http://dx.doi.org/10.1362/026725799784870432

De Chernantony, L. (2001). From Brand Vision to Brand Evaluation. Oxford: Butterworth \& Heinmann.

Devine, I., \& Halpern, P. (2001). Implicit Claims: The Role of Corporate Reputation in Value Creation. Corporate Reputation Review, 4(1), 42-51. http://dx.doi.org/10.1057/palgrave.crr.1540131

Doorley, J., \& Garcia, H. (2007). Reputation Management: The Key to Successful Public Relations and Corporate Communications. London: Routledge.

Dowling, G. R. (2001). Creating corporate reputations: Identity, image, and performance. Oxford, New York: Oxford University Press.

Dutton, E. J., Dukerih, M. J., \& Harquail, V. C. (1994). Organizational images and member identification. Administrative Science Quarterly, 39(2), 239-263. http://dx.doi.org/10.2307/2393235

Ellwood, I. (2000). The Essential Brand Book: Over 100 Techniques to Increase Brand Value. London: Kogan Page.

Fishbein, M., \& Ajzen, I. (1975). Belief, Attitude, Intention and Behavior: An Introduction to Theory and Research. Massachusetts: Addision-Wesley.

Fombrun, C., \& Shanley M. (1990). What's in a name? Reputation building and corporate strategy. Academy of Management Journal, 33, 233-258. http://dx.doi.org/10.2307/256324

Fombrun, C. J., Gardberg, N. A., \& Sever, J. M. (2000). The reputation quotient: A multi-stakeholder measure of corporate reputation. The Journal of Brand Management, 7(4), 241-255.

Fombrun, C. (2007). List of Lists: A Compilation of International Corporate Reputation Ratings. Corporate Reputation Review, 10(2), 144-153. http://dx.doi.org/10.1057/palgrave.crr.1550047

Fombrun, C. J. (1996). Reputation: realizing value from the corporate image. Boston, MA: Harvard Business School Press.

Fombrun, Ch. J., \& Van Riel, C. B. M. (2004). Fame \& Fortune: How Successful Companies Build Winning Reputations. FT: Prentice Hall.

Fombrun, J. C., \& Rindova, P. V. (1996). Who's tops and who decides? The social construction of corporate reputations. Unpublished manuscript, New York, New York University, Stern School of Business.

Fombrun, C., \& Rindova, V. (1998). Reputation Management in Global 1000 Firms: A Benchmarking Study. Corporate Reputation Review, 1(3), 205-214. http://dx.doi.org/10.1057/palgrave.crr.1540044

Foreman, A., \& Argenti, P. (2005). How Corporate Communication Influences Strategy Implementation, Reputation and the Corporate Brand: An Exploratory Qualitative Study. Corporate Reputation Review, 8(3), 245-264. http://dx.doi.org/10.1057/palgrave.crr.1540253

Gardberg, M. E., \& Hartwick, J. (1990). The Effects of Advertiser Reputation and Extremity of Advertising Claims on Advertising Effectiveness. Journal of Consumer Research, 17(September), 172-179.

Gotsi, M., \& Wilson, A. M. (2001). Corporate reputation: seeking a definition. Corporate Communications, 6(1), 24-30. http://dx.doi.org/10.1108/13563280110381189

Gray, Edmund R., \& Balmer, John M. T. (1998). Managing Corporate Image and Corporate Reputation. Long Range Planning, 31, 695-702. http://dx.doi.org/10.1016/S0024-6301(98)00074-0

Groenland, E. A. G. (2002). Qualitative research to validate the RQ - dimensions. Corporate Reputation Review, 4(4), 308-15. http://dx.doi.org/10.1057/palgrave.crr.1540152

Grupp, R. W., \& Gaines-Ross, L. (2002). Reputation Management in the Biotechnology Industry. Journal of Commercial Biotechnology, 9(1), 17-26. http://dx.doi.org/10.1057/palgrave.jcb.3040003

Handelman, J. M., \& Arnold, S. J. (1999). The role of marketing actions with a social dimension: Appeals to the institutional environment. Journal of Marketing, 63, 33-48. http://dx.doi.org/10.2307/1251774

Hatch, M. J., \& Schultz, M. (1997). Relationship between organizational culture identity and image. European Journal of Marketing, 31(5/6), 356-365. http://dx.doi.org/10.1108/eb060636

Hatch, M. J., \& Schultz, M. (2003). Bringing the Corporation into Corporate Branding. European Journal of Marketing, 37(7/8), 1041-1064. http://dx.doi.org/10.1108/03090560310477654 
Helm, S. (2005). Designing a formative measure for corporate reputation. Corporate Reputation Review, 8(2), 95-109. http://dx.doi.org/10.1057/palgrave.crr.1540242

Helm, S. (2007a). One reputation or many? Comparing stakeholders' perceptions of corporate reputation. Corporate communications: An international Journal, 12(3), 238-254.

Helm, S. (2007b). The Role of Corporate Reputation in Determining Investor Satisfaction and Loyalty. Corporate Reputation Review, 10(1), 22-37. http://dx.doi.org/10.1057/palgrave.crr.1550036

Hillenbrand, C., \& Money, K. (2006). Using Reputation measurement to create value: An analysis and integration of existing measures. Journal of General Management, 32(1), 1-12.

Ind, N. (1997). The corporate brand. Basingstoke, England: Macmillan. http://dx.doi.org/10.1057/9780230375888

Klein, P. (1999). Measure what Matters: Corporate Image. Communication World, 16(9), 32.

Knox, S., \& Bickerton, D. (2003). The six conventions of corporate branding. European Journal of Marketing, 37(7/8), 998-1016. http://dx.doi.org/10.1108/03090560310477636

Lavidge, R. (1961). A Model for Predictive Measurements of Advertising Effectiveness. Journal of Marketing, 25(October), 59-63. http://dx.doi.org/10.2307/1248516

Le Roux, JRJ. (2003). Corporate Reputation in the Information Technology Industry: A South African Case Study. Thesis, Faculty of Economic and Management Sciences, University of Pretoria.

Little, P. L., \& Little, B. L. (2000). Do perceptions of corporate social responsibility contribute to explaining differences in corporate price-earnings ratios? A research note. Corporate Reputation Review, 3(2), 137-142. http://dx.doi.org/10.1057/palgrave.crr.1540108

Logsdon, J. M., \& Wood, D. J. (2002). Reputation as an Emerging Construct in the Business and Society Field: An Introduction. Business \& Society, 41(4), 365-370. http://dx.doi.org/10.1177/0007650302238773

Mahon, J. F. (2002). Corporate reputation: A research agenda using strategy and stakeholder literature. Business and Society, 41(4), 415-446. http://dx.doi.org/10.1177/0007650302238776

Melewar, T. C., \& Wooldridge, A. (2001). The dynamics of corporate reputation. The Journal of Communication Management: An International Journal, 5(4), 327-40.

Milewicz, J., \& Herbig, P. (1994). Evaluating the brand extension decision using a model of reputation building. Journal of Product and Brand Management, 3(1), 39-47. http://dx.doi.org/10.1108/10610429410053077

Mottram, S. (1998). Branding the corporation. In Hart, S. \& J. Murphy, (Eds.), Brands: The New Wealth Creators. Basingstoke: Palgrave and Interbrand.

Musteen, M., Datta, D.K., \& Kemmerer, B. (2010). Corporate Reputation: Do Board Characteristics Matter? British Journal of Management, 21, 498-510.

Nakra, P. (2000). Corporate Reputation Management: CRM with a Strategic Twist. PublicRelations Quarterly, 45(2), 35-42.

Nguyen, N., \& Gaston L. (2001). Corporate image and corporate reputation in customers' retention decisions in services. Journal of Retailing and Consumer Services, 8(4), 227-236. http://dx.doi.org/10.1016/S0969-6989(00)00029-1

Olins, W. (1978). The Corporate Personality: An Inquiry into the Nature of Corporate Identity. London: Design Council.

Puncheva-Michelotti, P., \& Michelloti, M. (2010). The Role of the Stakeholder Perspective in Measuring Corporate Reputation. Marketing Intelligence and Planning, 28(3), 249-274. http://dx.doi.org/10.1108/02634501011041417

Rao, H. (1994). The social construction of reputation: Certification contests, legitimation, and the survival of organizations in the American automobile industry 1895-1912. Strategic Management Journal, 15(1), 29-44. http://dx.doi.org/10.1002/smj.4250150904

Ressler, J., \& Abratt, R. (2009). Assessing the Impact of University Reputation on Stakeholder Intentions. Journal of General Management, 35(1), 35-45.

Rhee, M., \& Haunschild, P. (2006). The Liability of Good Reputation: A study of Product Recalls in the US Automobile Industry. Organization Science, 17(1), 101-117. http://dx.doi.org/10.1287/orsc.1050.0175 
Rindova, V. P., \& Kotha, S. (2001). Continuous 'Morphing': Competing Through Dynamic Capabilities, Form and Function. Academy of Management Journal, 44(6), 1263-1280. http://dx.doi.org/10.2307/3069400

Rosenberg, M., \& Hovland, C. (1960). Cognitive, Affective and Behavioral Components of Attitudes. In Hovland, C., \& Rosenberg, M. (Eds.), Attitude, Organization and Change (pp. 1-14). New Haven: Yale University Press.

Saxton, M. K. (1998). Where Do Corporate Reputations Come From? Corporate Reputation Review, 1(4), 393-399. http://dx.doi.org/10.1057/palgrave.crr.1540060

Shamma, H., \& Hassan, S. (2009). Customer and Non-customer Perspectives for Examining Corporate Reputation. Journal of Product and Brand Management, 18(5), 326-337. http://dx.doi.org/10.1108/10610420910981800

Sobol. M., Farelly, G. E., \& Tapper, J. S. (1992). Shaping the Corporate Image: An Analytic Guide for Executive Decision Makers. New York: Quorum Books.

Spence, A. M. (1974). Market Signaling: Informational Transfer in Hiring and Related Screening Processes. Cambridge, Massachusetts: Harvard University Press.

Stuart, T., Hoang, H., \& Hybels, R. C. (1999). Interorganizational Endorsements and the Performance of Entrepreneurial Ventures. Administrative Science Quarterly, 44(2), 315-339. http://dx.doi.org/10.2307/2666998

Turban, D. B., \& Greening, D. W. (1997). Corporate social performance and organizational attractiveness to prospective employees. Academy of Management Journal, 40(3), 658-672. http://dx.doi.org/10.2307/257057

Van Riel, C. B. M. (1995). Principles of corporate communication. London, New York: Prentice Hall.

Vendelo, M. T. (1998). Narrating corporate reputation. International Studies of Management \& Organization, 28(3), 120-137.

Walker, K. (2010). A Systematic Review of the Corporate Reputation Literature: Definition, Measurement, and Theory. Corporate Reputation Review, 12(4), 357-387. http://dx.doi.org/10.1057/crr.2009.26

Wang, Y., Kandampully, H. P. L., \& Shi, G. (2006). The Role of Brand Equity and Corporate Reputation in CRM: A Chinese Study. Corporate Reputation Review, 9(3), 179-197. http://dx.doi.org/10.1057/palgrave.crr.1550027

Wartick, L. S. (2002). Measuring Corporate Reputation, Definition and Data. Business \& Society, 41(4), 371-392. http://dx.doi.org/10.1177/0007650302238774

Weiss, A., Anderson, E., \& MacInnis, D. J. (1999). Reputation Management as a Motivation for Sales Structure Decision. Journal of Marketing, 63(4), 74-89. http://dx.doi.org/10.2307/1251975

Wernerfelt, B. (1998). Umbrella Branding as a Signal of New Product Quality: An Example of Signalling by Posting a Bond. RAND Journal of Economics, 19, 458-466. http://dx.doi.org/10.2307/2555667

Wilson, R. (1985). Reputations in games and markets. In Roth, A. (Ed.), Game-theoretic Models of Bargaining (pp. 65-84). Cambridge University Press, NY. http://dx.doi.org/10.1017/CBO9780511528309.004 